\title{
Spectrophotometric Determination of Bisacodyl in Pure and Pharmaceutical Preparation via Oxidative Coupling Organic Reaction
}

\author{
Iqbal S. Mohammed* \\ Amal H. Mhemeed ** \\ Khansaa A. Nasser* \\ *Department of Chemistry, Diyala University, Diyala, Iraq. \\ **College of Pharmacy, Misan University, Misan, Iraq. \\ E-mail: ikbalsalman76@yahoo.com
}

Received 2/3/2016

Accepted $3 / 8 / 2016$

(c) (1) ब

(1) This work is licensed under a Creative Commons Attribution-Non Commercial-No Derivatives 4.0 International License

\begin{abstract}
:
A simple, accurate and sensitive spectrophotometric way is used to determine Bisacodyl in pure and pharmaceutical preparations. The proposed method depends on using 2,4-Dinitrophenylhydrazine as chromogenic reagent. The method was based on the oxidative coupling reaction of Bisacodyl with 2,4-Dinitrophenylhydrazine with Sodium periodate in the presence of sodium hydroxide as alkaline media to form red water soluble dye product, that has a maximum absorption at $\lambda \max 522 \mathrm{~nm}$. Beer 's law is obeyed in the concentration of $(2.00-20.00) \mu \mathrm{g} . \mathrm{ml}^{-1} 1$.The molar absorptivity is (6505) L. mol ${ }^{-1} . \mathrm{cm}^{-1}$, a sandall sensitivity of $\left.(0.0555) \mu \mathrm{g} . \mathrm{cm}^{-2}\right)$, correlation coefficient of (0.9970), Limitof detection (LOD) $\left(0.0312 \mu \mathrm{g} \cdot \mathrm{ml}^{-1}\right)$, limit of Quantitation (LOQ) $\left(0.3125 \mu \mathrm{g} . \mathrm{ml}^{-1}\right)$ and the relative standard deviation of RSD\% (1.6). The method gave a successful determination for Bisacodyl in pharmaceutical preparations and the value of recovery $\%$ was better than $(100.16 \%)$.
\end{abstract}

Key words: Bisacodyl drug, Spectrophotometric determination, Pharmaceutical preparation

\section{Introduction:}

Bisacodyl is 4,4 (pyrid - 2 ylmethylene) bis (phenyl acetate)[ $\left.\mathrm{C}_{22} \mathrm{H}_{19} \mathrm{NO}_{4}=361.4\right]$ Figure(1) is a laxative used for the treatment of constipation, for evacuation of the colon before radiological of the abdomen, or endoscopy, and before or after surgical operations. It has a little or no action on the small intestine. It stimulates the rectal mucosa, which raises peristaltic movements and causing defecation in 15-
30 minutes[1-5] .Doses of 5 to 10 milligrams may be given by mouth and act within 6 to 12 hours.Suppositories of 10 milligrams given by rectum act within one hour.Children under 10 years may be given5 milligrams by mouth or by rectum[6-8]. The literature survey reveals that only few methods have been reported for determination of Bisacodyl in pure form and in pharmaceutiacal 
Formulations [9-13]. Bisacodyl has been determined by various pharmacopeial and nonpharmacopeial methods. The official methods involve non aqueous titration for Bisacodyl suppositories, spectrophotometry [14-16].For enteric coated tablets, and high-performance liquid chromatography (HPLC) [17] for both suppositories and enteric coated tablets. The non pharmacopeial methods for Bisacodyl determination involve spectrophotometry for combinations with piribedil [18].Gas chromatography (GC) in pharmaceutical tablets; GC in urine, serum, and stool [19].

The proposed method is based on the reaction of the Bisacodyl drug with 2,4dinitrophnylhydrazine in the presence of sodium periodate in alkaline medium to form a red water soluble dye product which gave an absorption maximum at $522 \mathrm{~nm}$.

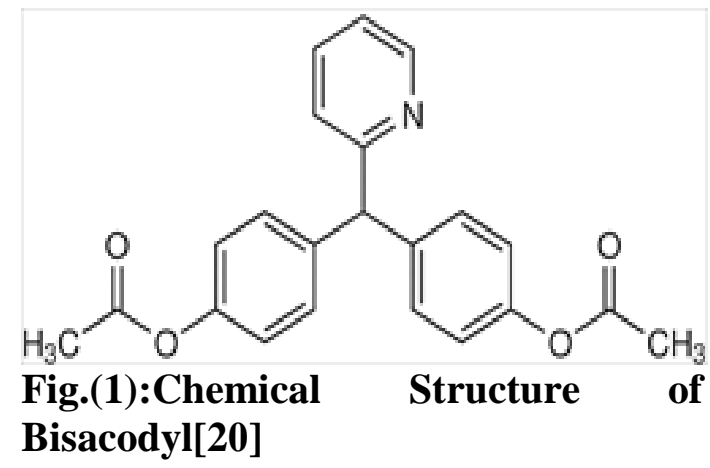

Materials and Methods:Apparatus

UV-visible, shimadzu 1700 spectrophotometer, with $1.0 \mathrm{~cm}$ quartz cells was used for absorption measurements,

-WTW $720 \mathrm{pH}$ meter .

- Electronic balance, sartorius AG gottingen B2 2105 Germany..

\section{Reagents}

All chemicals used were of analytical reagent or pharmaceutical grade and distilled water was used throughout the work.

-Stock solutions from drug (1000 $\mu \mathrm{g}$. $\mathrm{ml}^{-1}$ ) of Bisacodyl (SDI - Iraq) were prepared by dissolving (1gm) of Bisacodyl in $(0.5 \mathrm{ml})$ of concentration sulphuric acid and diluting to the mark in $1000 \mathrm{ml}$ volumetric flask. Working solutions were prepared by diluting the solution in distilled water.

-Stock solution of 2,4Dinitrophenylhydrazine $(0.01 \mathrm{M})$ was prepared by dissolving (0.01980 gm ) of 2,4- Dinitro phenyl hydrazine in ethanol and the solution made up to the mark in $100 \mathrm{ml}$ volumetric flask with ethanol.

- Stock solution of Sodiume periodate $(0.01 \mathrm{M})$ was prepared by dissolving $(0.213 \mathrm{gm})$ of $\mathrm{NaIO}_{4}$ in distilled water and diluting to mark in $100 \mathrm{ml}$ volumetric flask.

- Stock solution of Sodium hydroxide $(\mathrm{NaOH})(1.00 \mathrm{M})$ was prepared by dissolving $(4 \mathrm{gm})$ of $\mathrm{NaOH}$ in distilled water and diluting to the mark in $100 \mathrm{ml}$ volumetric flask and then standardization of this solution with standard solution of $\mathrm{HCl}$.

\section{Procedure for assay of Bisacodyl in pharmaceutical preparations Tablets:}

Bisacodyl tablets, provided from (SDI) Samara-Iraq (10) tablets were powdered and a amount of the final powder was accurately weighted to give an equivalent to about $10 \mathrm{mg}$ of Bisacodyl was dissolved in distilled water. The prepared solution transferred to $100 \mathrm{ml}$ volumetric flask and made up to the mark with distilled water forming a solution of $100 \mu \mathrm{g} \cdot \mathrm{ml}^{-1}$ concentration. The solution was filtered by Whitman paper to avoid suspended particles. These solutions were diluted quantitatively to form a concentrations in the range of calibration curve.

\section{Recommended procedures:}

Into a series of $25 \mathrm{ml}$ volumetric flask, transfer an increasing volume of Bisacodyl solution $\left(100 \mu \mathrm{g} \cdot \mathrm{ml}^{-1}\right)$ to cover the range of calibration curve $(2.00-20.00) \mu \mathrm{g} \cdot \mathrm{ml}^{-1}$, 
added $\quad 0.5 \mathrm{ml} \quad(0.01 \mathrm{M})$ of 2,4Dinitrophenylhydrazine and shake well . Added1.0 $\mathrm{ml}(0.01 \mathrm{M}) \quad$ Sodiume periodate. added $1.0 \mathrm{ml}(1.0 \mathrm{M})$ of $\mathrm{NaOH}$, diluted to the mark with distilled water, and allow the flasks to stand for $30 \mathrm{~min}$ at room temperature $\left(25^{\circ} \mathrm{c}\right)$. Measure the absorption at ( $522 \mathrm{~nm}$ ) against the blank prepared in the same method but no Bisacodyl.

\section{Results and Discussion:}

Bisacodyl drug react with 2,4Dinitro phenyl hydrazine and Sodium periodate in the presence of sodium hydroxide as alkaline media to form an intense red color product that can be measured spectrophotometrically at 522 nmFigure(1).

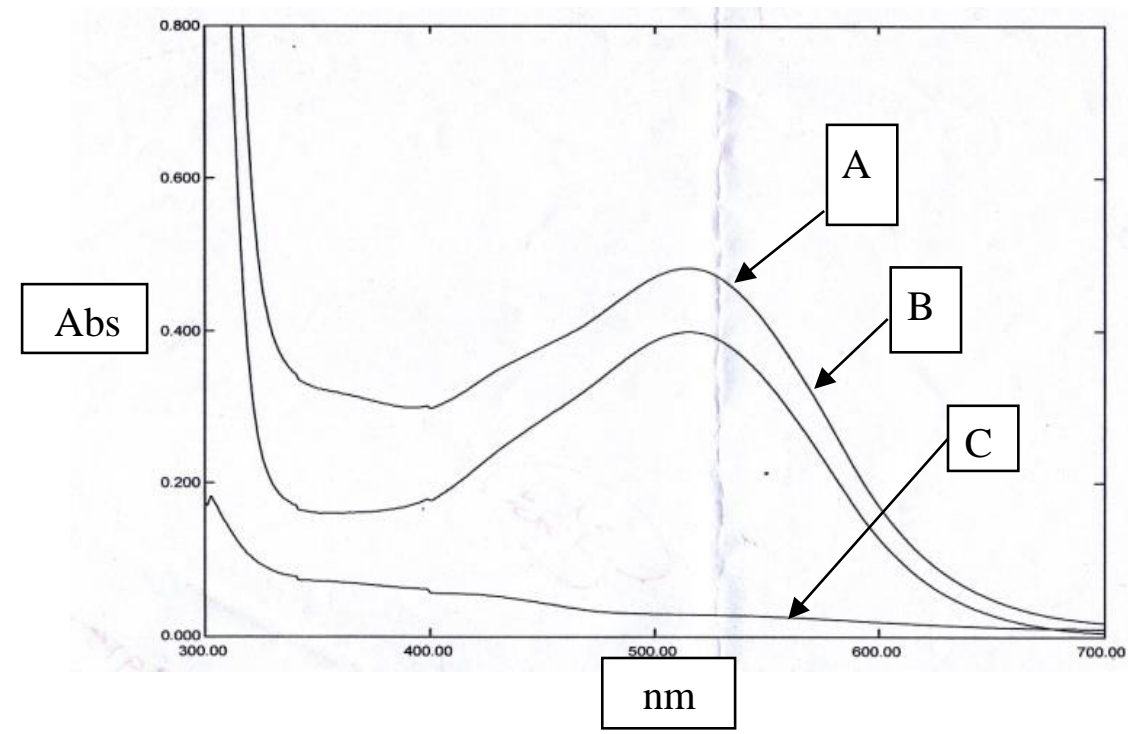

A:Bisacodyl Vs distilled water

B: Bisacodyl Vs Blank C: Blank Vs distiled water

Fig. (1): Absorption spectra of (A) Bisacodyl versus distilled water (B) Bisacodyl versus Blank $(\mathrm{C})$ Blank versus water.

Study of the optimization Experimental Condition:

The effect of various parameters such as a mount of reactants, order of addition, time and temperature were studied.

Effect of 2,4- Dinitro phenyl hydrazine Volume:

The effect of various volume of 2,4dinitrophenylhydrazine were investigated. A Volume of $(1.4 \mathrm{ml})$ of $(0.01 \mathrm{M})$ of reagent show the highest absorbance at $522 \mathrm{~nm}$ and was chosed for further use. the results are shown in Figure(2) .

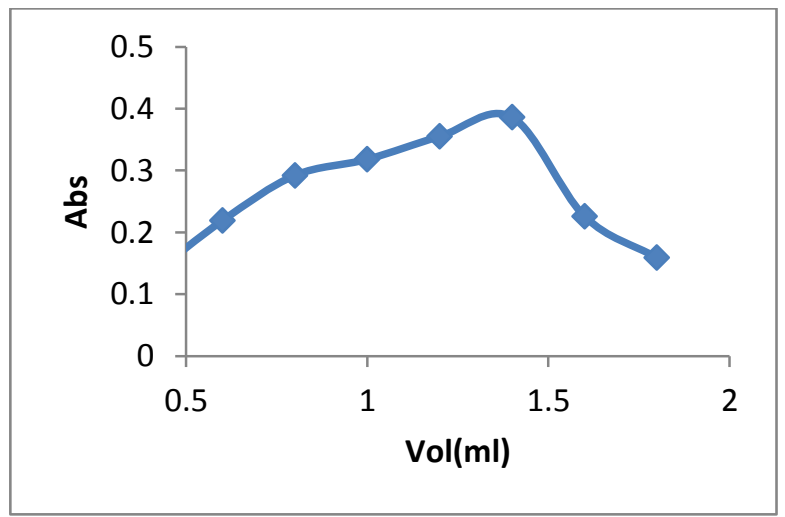

Fig. (2): The Effect of 2,4Dinitrophenylhydrazine of $(0.01 M)$ volume 


\section{The Effect of Sodium periodate $\mathrm{NaIO}_{4}$} Volume:

The effect of $\mathrm{NaIO}_{4}$ volume was studied. Avolume of $(2 \mathrm{ml})$ of $(0.01 \mathrm{M})$ gave the higher absorption intensity at $\lambda_{\max } 522 \mathrm{~nm}$. Figure(3) and thus was selected as optimum volume for further use.

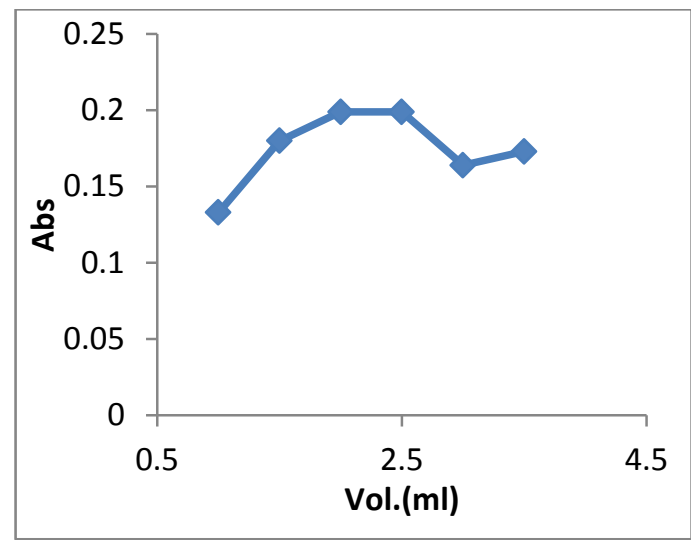

Fig.(3): The Effect of Sodium periodate $\mathrm{NaIO}_{4}$ of $(0.01 \mathrm{M})$ volume.

\section{Effect of alkaline media type:}

Bisacodyl drug react with Dinitro pheny lhydrazin in the presence of alkaline medias therfore the type of alkaline media is an obtained showed that sodium hydroxide gave the best absorbance Table(1) and was used in the general procedure.

Table (1): The effect of Base media type

\begin{tabular}{|c|c|}
\hline Base $(0.01) \mathrm{M}$ & Abs. \\
\hline $\mathrm{NaOH}$ & 0.386 \\
\hline $\mathrm{KOH}$ & 0.302 \\
\hline $\mathrm{Ca}(\mathrm{OH})_{2}$ & 0.285 \\
\hline $\mathrm{Ba}(\mathrm{OH})_{2}$ & 0.313 \\
\hline $\mathrm{NH}_{4} \mathrm{OH}$ & 0.318 \\
\hline $\mathrm{Na}_{2} \mathrm{CO}_{3}$ & 0.183 \\
\hline $\mathrm{NaHCO}_{3}$ & 0.201 \\
\hline
\end{tabular}

The Effect of Sodium hydroxide $\mathrm{NaOH}$ volume:

The effect of $\mathrm{NaOH}$ volume was similarly studied.Avolum of $(0.6 \mathrm{ml})$ of (1M ) $\mathrm{NaOH}$ gave the higher absorption intensity at $522 \mathrm{~nm}$ Figure (4).

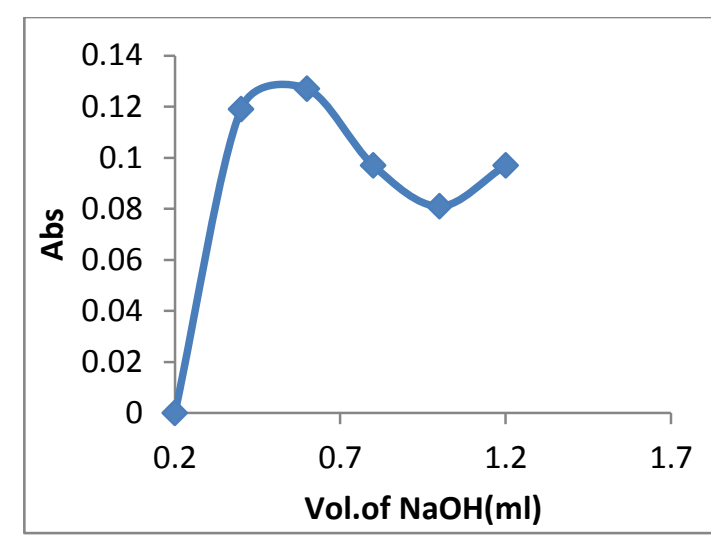

Fig.(4): The Effect of $\mathrm{NaOH}$ (1M)Volume

\section{The Effect of order of addition:}

The effect of order of reagents addition on the absorption of red product dye was investigated. Table(2) shows the order of addition could be followed,(Drug:2,4-

Dintrophenylhydrazin: $\mathrm{NaIO}_{4}: \mathrm{NaOH}$ ). Due to show the highest absorption and thus was selected for further use.

Table (2): The Effect of order of addition.

\begin{tabular}{|c|c|c|}
\hline Order of addition & $\begin{array}{c}\text { Absorbance } \\
\text { at } \lambda \text { max } \\
(522) \mathrm{nm}\end{array}$ & $\mathrm{NO}$ \\
\hline $\begin{array}{c}\text { Drug:2,4 } \\
\text { Dintrophenylhydrazin: } \mathrm{NaIO}_{4}: \mathrm{NaOH}\end{array}$ & 0.398 & 1 \\
\hline $\begin{array}{c}\text { 2,4-Dintrophenylhydrazin: } \\
\text { Drug: } \mathrm{NaIO}_{4}: \mathrm{NaOH}\end{array}$ & 0.397 & 2 \\
\hline $\begin{array}{c}\text { Drug: } \mathrm{NaIO}_{4}: 2,4- \\
\text { Dintrophenylhydrazin: } \mathrm{NaOH}\end{array}$ & 0.372 & 3 \\
\hline $\begin{array}{c}\text { 2,4-Dintrophenylhydrazin: } \mathrm{NaIO}_{4} \\
\text { :Drug:NaOH }\end{array}$ & 0.231 & 4 \\
\hline $\begin{array}{c}\text { 2,4-Dintrophenylhydrazin: } \mathrm{NaOH}_{2} \\
\text { Drug:NaIO}\end{array}$ & 0.128 & 5 \\
\hline $\begin{array}{c}\text { Drug: } \mathrm{NaOH}: 2,4- \\
\text { Dintrophenylhydrazin: } \mathrm{NaIO}_{4}\end{array}$ & 0.209 & 6 \\
\hline
\end{tabular}

\section{The Effect of Temperature:}

The influence of Temperature on determined color intensity of the product was evaluated in practice the highest absorption was obtained when the product color was developed at $\left(25^{\circ} \mathrm{c}\right)$ Figure(6). 


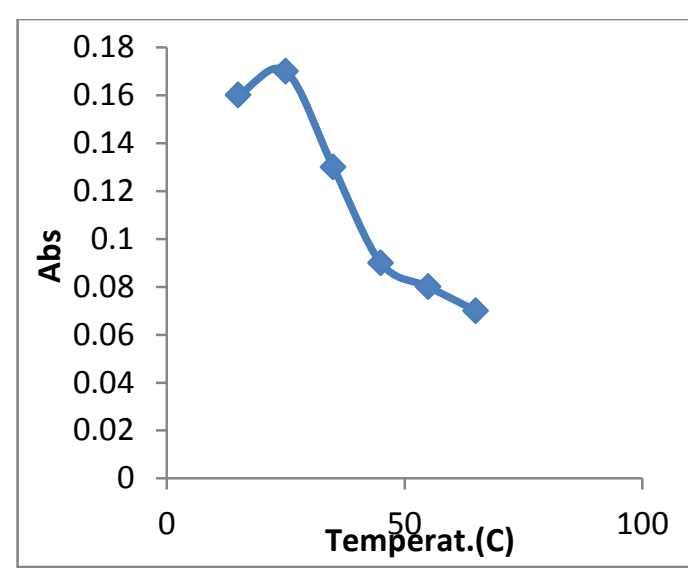

Fig.(6) : The Effect of Temperature

\section{The Effect of reaction Time:}

The color intensity reached its maximum absorption after Bisacodyl has been reacted with 2,4Dintrophenylhydrazin, $\mathrm{NaIO}_{4}$ and $\mathrm{NaOH}$ at $10 \mathrm{~min}$. Thus $10 \mathrm{~min}$ development time was chosen for further use. The results obtained are shown in Figure (7)

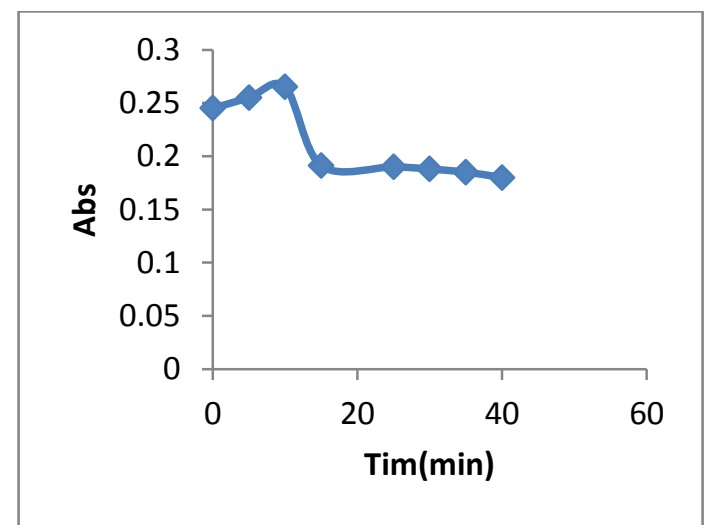

Fig.(7) : The Effect of Time

\section{Calibration Curve:}

Using optimum conditions, a linear calibration curve for the determination of Bisacodyl was determined over the concentration range of $(2.0-20.0)$ $\mu \mathrm{g} . \mathrm{ml}^{-1}$. The linear regression equation for the determination of Bisacodyl is $(\mathrm{Y}=0.018 \mathrm{X}+0.176)$ and correlation coefficient of 0.9970 The linear calibration graph is shown in Figure(8).
The statistical treatments of the analytical data are shown in Table(3).

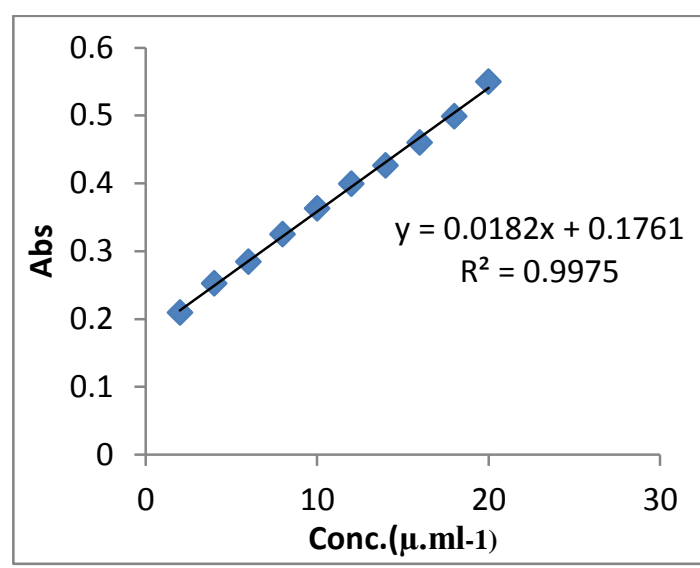

Fig. (8): Calibration Curve for the determination of Bisacodyl .

Table (3): Optical characteristics and statistical data for the determination of Bisacodyl.

\begin{tabular}{|c|c|}
\hline Parameter & value \\
\hline$\lambda$ max $(\mathrm{nm})$ & 522 \\
\hline Color & red \\
\hline Linearity range $\left(\mu \mathrm{g} . \mathrm{ml}^{-1}\right)$ & $2.0-20.0$ \\
\hline Regression equation & $\begin{array}{c}\mathrm{Y}=0.018 \mathrm{X}+0 . \\
176\end{array}$ \\
\hline Calibration Sensitivity $(\mathrm{ml}$. & 0.018 \\
$\left.\mu^{-1}\right)$ & 0.9984 \\
\hline Correlation Coefficient $(\mathrm{r})$ & 0.9970 \\
\hline Correlation of linearity $\left(\mathrm{R}^{2}\right)$ & 6505 \\
\hline Molar absorptivity $\left(\mathrm{L} \cdot \mathrm{Mol}^{-1} . \mathrm{Cm}^{-1}\right)$ & 0.0555 \\
\hline Sandells Sensitivity $\left(\mu \mathrm{g} . \mathrm{Cm}^{-2}\right)$ & 0.0312 \\
\hline L.O.D $\left(\mu \mathrm{gg} \cdot \mathrm{ml}^{-1}\right)$ & 0.3125 \\
\hline L.O.Q $\left(\mu \mathrm{gg} . \mathrm{ml}^{-1}\right)$ &
\end{tabular}

\section{Nature of the dye product:}

The stoichiometry of the reaction between Bisacody 1,2,4Dinitrohydrazine, $\mathrm{NaIO}_{4}$ and $\mathrm{NaOH}$ was investigated using the mole ratio and Slope ratio method [21-24] unsing the optimized conditions. The results in Figure (9), (10), show a 1:1 drug to reagent product were formed. Therefore the formation of the product may probably occurs as follows: 

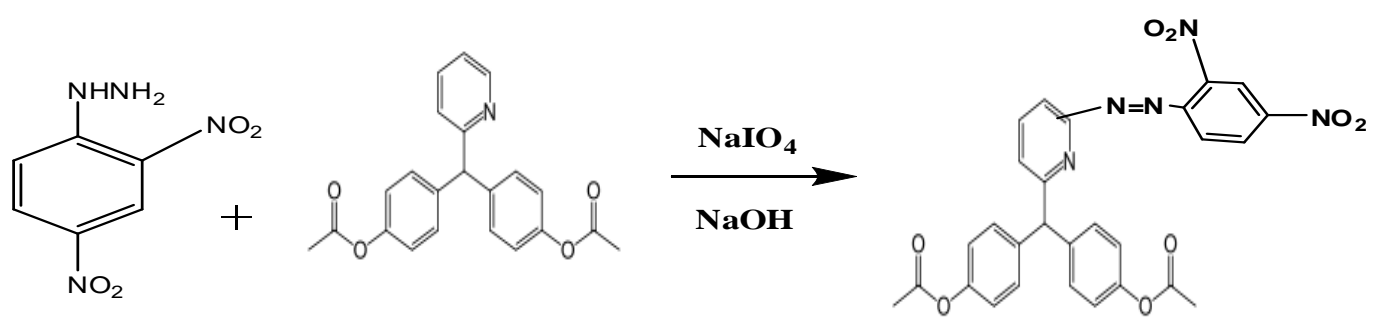

Dinitrophenylhydrazine

Bisacodyl

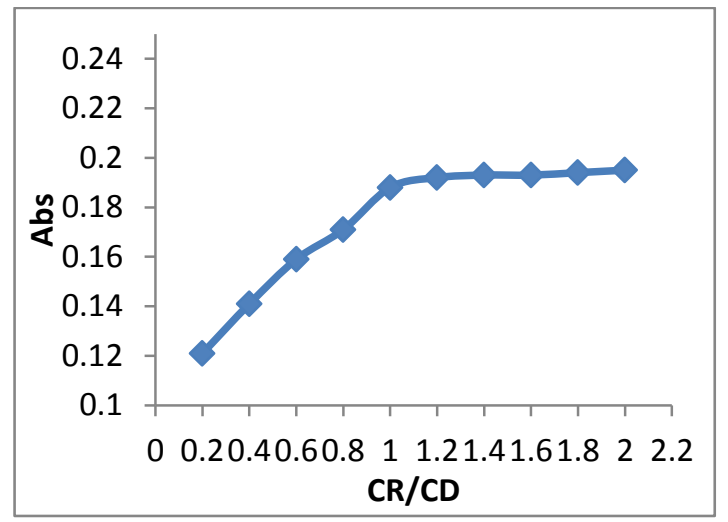

CR:concentration of reagent

CD:concentration of drug

Fig. (9): Molar ratio of drug to reagent

\section{Analytical Application:}

Proposed method has been applied for the determination of Bisacodyl drug in pharmaceutical preparations with good accuracy and precision for the

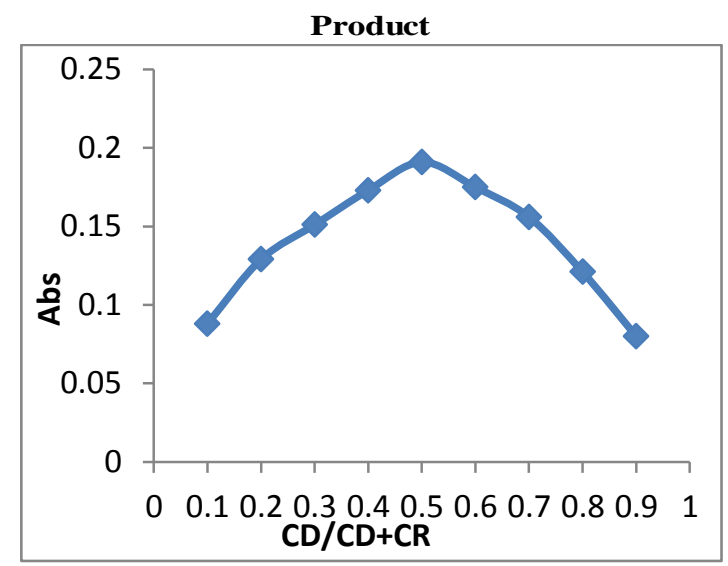

$\mathrm{CR}$ :concentration of reagent

CD:concentration of drug

\section{Fig.(10): Continuous \\ Method \\ Variation}

drugs studied. The results obtained were given in Table(4) which confirm Finally, the proposed procedure was compared successfully with the standard procedure Table(3).

Table (4): Application of the proposed procedure for the determination of Bisacodyl in pharmaceutical preparations.

\begin{tabular}{|c|c|c|c|c|}
\hline Conc. Of Bisacodyl $[\boldsymbol{\mu g} / \mathbf{m l}]$ & $\boldsymbol{R E} \%$ & Recovery \% & \multirow{2}{*}{ Average recovery \% } & \multirow{2}{*}{ RSD \% } \\
\hline 4 & $\boldsymbol{0 . 2 4}$ & 100.24 & \multirow{2}{*}{100.16} & 1.6 \\
\hline 8 & 0.122 & 100.122 & & 0.22 \\
\hline 12 & 0.14 & 100.14 & & 0.2 \\
\hline
\end{tabular}

\section{Conclusion:}

A simple, accurate and excellent spectrophotometric method was investigated for the determination of Bisacodyl in pure and in pharmaceutical preparations. The proposed method can be carried out with no need for further steps such as solvent extraction step, $\mathrm{pH}$ or Temperature control .

\section{References:}

[1] Metwally, F.; Abdelkawy, M.and Naguib, I. 2007. Development andvalidation of three stabilityindicating methods for determination of bisacodyl in pure form and pharmaceutical preparations. JAOAC Int.,90(10):113-27.

[2] parfitt, K.; Blake, SC.; Parsons, PS. and Martindale, AV. 2005. The Extra pharmacopoeia, 32nd edition, pharmaceutical press: London, $1251 \mathrm{P}$.

[3] Rachmilewitz, D.; Karmeli, F. and Okon, E. 1980. Effect of bisacodyl on CAMP and Prostaglandin E2 
content, $(\mathrm{Na}+\mathrm{k}) . \quad$ ATP ase, adenylcyclase, and phosphodiesterase activities of ratintestine. Dig Dis sci., 25(8):602-607.

[4] Bradshaw, K. ; Burnett, J. and Sidhu, A. 1995. Highperformance liquid chromatographic determination of bisacodyl in pharmaceuticaldosage forms marketed in Australia.JPBA, 13(11),1355-1362.

[5] Mohamed, M. B.; Mohamed, E. E. and Arwa, M. I. 2015. spectrophotometric determinatonof Bisacodyl in pure form and tablet form. AJPAMC,3(1): 1- 13.

[6] Basavaiah, K. and Somashekar,

B. 2007.Quantitation of rantidine in pharmaceuticals by titrimetry and spectrophotometry using dichromateas the oxidimetric reagent. J IranChem Soc,4(2): 7888.

[7] Nief, R. and Nawal, A. M. 2011. Indirect spectrophotometric method for the determation of bisacodyl in commercial dosage forms and in environmenta 1 water samples. Irq $\mathbf{J}$ Pharm, 11(2): 77-81.

[8] Pamela, C. C.; Richard, F.; Michelle, A .C. and Luigi. X. C. 2006. Illustrated Reviews: Pharmacology, Lippincott Williams and Wilkins, Baltimor, $3^{\text {rd }}$ Ed, PP 333.

[9] Barar, F. S. K. 2008. Essentials of Pharmacotherapeutics, New Delhi, 4th Ed, PP 539.

[10] Ramin, M. and Amir, A. 2006. Jouyban A. Amembrane Sensor for selective determination of bisacodyl in tablets. J Chin Chemi Soc, 53(11):613-18.
[11] Mohamed, H.; Suzy, M.; Magda, H. and Tarek, S. 2004. Spectrophotometric detemination of bisacodyl and piribedil. Anal. Lett,37(2):247-262

[12] Fadia, H.; Abdelkawy, M. and Ibrahim, A. 2007. Development and validation of three stability indicating methods for determination of bisacodyl in pure form and pharmaceutical preparations. J AOAC int, 90(1):113-127.

[13] Laik, S. A. 1979. Detemination of bisacodyl and its hydrolysis products in bisacodyl formulations by high preformance liquid chromatography. Fresenius Z. Anal Chem, 299 (83):124-126.

[14] Campbell, A. N. and Sherma, J. 2003. Development and validation of ahigh performance thin-layer chromatographic method densitometric detection for determination of bisacodyl in pharmaceutical tablets. Acta chromatographica, 13:109-16.

[15] Parandis, D.; Parvz, N. and Reza, G. M. 2009. Rapid determination of bisacodyl in flow-injection system combination by a novel sensitive square-ware voltammetry, Sensors and Actuators B: Chemical 136(1):66-72.

[16] Elvis, A. M. and Deepali, M. G. 2011. Development and validation of UV spectrophotometric method for determination of bisacodyl in suppositories. Int. J. Pharm Tech Res,3(1):193-196.,.

[17] Massaccesi, M. 1987. Chromatographic determination of two drugs: bisacodyl and sodium picosulphate. Ann. Chim. (Rome), 77:515-23

[18] Alaa, F.; Muneer, A. and Muhammad, H. 2012. Spectrophotometric determination of Levo-dopa in pharmaceutical preparationvia oxidative coupling organic reaction. Kerbala Journal of 
Pharmaceutical Sciences ,(4):145154.

[19] Abdel-Hay, M. H.; Sabry, S. M.; Barary, M. H. and Belal, T. S. 2004. Spectrophotometric determination of bisacodyl and piribedil. Anal. Lett, 37:247-62.

[20] Ibrahim, A. 2011. Stability indicating analysis of bisacodyl by partial least squares regression, spectral residual augmented classical least squares and support vector regression chemometric models: A comparative studym, Bulletin of Faculty of Pharmacy, Cairo University 49: 91-100

[21] Basavaiah, K. 2007. Rapid titrimetric and spectrophotometric methods for salbutamol sulphate in pharmaceuticals using Nbromosuccinimide, Acta Pharm. 57 87-98..
[22] Saadiyah, A.. 2011. New Azo Coupling Reactions for Visible Spectrophotometric Determination of Salbutamol in Bulk and Pharmaceutical Preparations. Dirasat, Pure Sciences, 38(2):153160.

[23] Saadiyah, A.; Amira, H. and Maha, K. 2010. Safety method, Spectrophotometric Determination of Sulfamethaxazole drug in bulk and Pharmaceutical Preparations.

Baghdad Science Journal. 7(1):1-7.

[24] Balyejjusaa, S.; Adomeb, R. O. and Musokec, D. Spectrophotometric determination of sulphamethoxazole and trimethoprim (co-trimoxazole) in binary mixtures and in tablets, Afr Health Sci. 2002 August; 2(2): 5662.
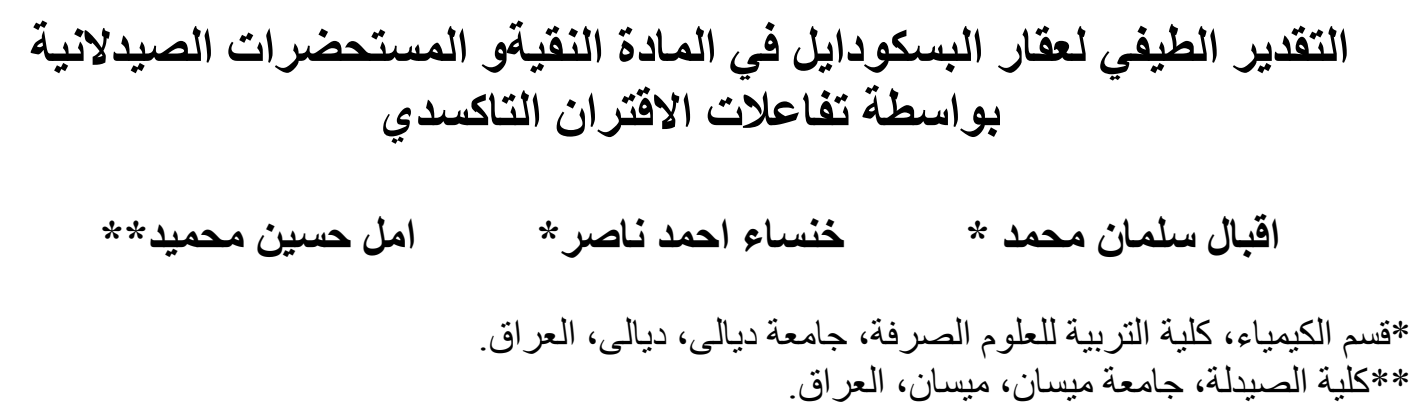